Ahlholm, M., I. Piippo \& P. Portaankorva-Koivisto (toim.) 2021. Koulun monet kielet. Plurilingualism in the school. AFinLA-e. Soveltavan kielitieteen tutkimuksia 2021 / n:o 13. 70-90.

\author{
Heini Lehtonen \\ Helsingin yliopisto
}

\title{
Kielitaitojen kirjo käyttöön, limittäiskieleilyä luokkaan
}

This paper focuses on pedagogical practices that enhance language awareness and encourage the use of the pupils' diverse linguistic repertoires in the classroom. The paper is based on the sociolinguistically informed action research project Itä-Helsingin uudet Suomen kielet. The data for this paper come from video recordings of the projects' workshops as well as interviews with the teachers. I describe the ways in which the pupils take the role of language experts in the project workshops and analyze how the project changed the pedagogical thinking and practices of the teachers. The analysis shows that transforming the monolingual institutional space into a translanguaging space is possible with language awareness and translanguaging pedagogy. In the translanguaging space, registers from different contexts encounter in shared practices, which allows learning beyond the borders of languages. Action research proves to be a fruitful way for implementing research knowledge and ideas in practice.

Keywords: diversity, classroom, translanguaging pedagogy, language awareness, action research

Asiasanat: kielellinen moninaisuus, luokkahuonevuorovaikutus, limittäiskieleilyn pedagogiikka, kielitietoisuus, toimintatutkimus 
KIELITAITOJEN KIRJO KÄYTTÖÖN,

LIMITTÄISKIELEILYÄ LUOKKAAN

\section{Johdanto: moninaisuus näkyväksi}

Tämän artikkelin keskiössä on kysymys siitä, miten koulun ja opetustilanteen yksikielisen institutionaalisen tilan normeja pedagogisin valinnoin muokataan sellaisiksi, että oppilaiden ja yhteisön monet kielet olisivat luonteva osa oppimista. Kysymystä tarkastellaan Itä-Helsingin uudet Suomen kielet -toimintatutkimushankkeessa kerätyn aineiston valossa.

On yhä harvinaisempaa, että suomalaisen koululuokan kaikkien oppilaiden ainoa, vahvin tai yksiselitteinen ensi- tai äidinkieli olisi koulun opetuskieli. Vuoden 2020 lopussa muun kuin suomen-, ruotsin- tai saamenkielisiä oli Suomen väestöstä 7,8 prosenttia (Tilastokeskus 2021). Tilasto ei kerro yksilöiden monikielisyydestä, sillä Suomessa äidinkielekseen voi ilmoittaa vain yhden kielen. Näistä reilusta neljästäsadasta tuhannesta "vieraskielisestä"1 moni taitaa myös suomea. "Vieraskielisiksi" tilastoitujen määrä kasvaa nopeasti: ennusteen mukaan vuonna 2030 joka neljäs helsinkiläinen puhuu äidinkielenään muuta(kin) kuin suomea, ruotsia tai saamea (Tilastokeskus 2019). Muutakin kuin suomea, ruotsia tai saamea jo lapsena puhuvien alaikäisten määrä kasvaa nopeammin kuin kantaväestön. Tämä tarkoittaa sitä, että kouluissa kasvaa niiden oppilaiden osuus, jotka puhuvat kotona muutakin kuin koulun opetuskieltä. Jo nyt esimerkiksi Itä- ja Koillis-Helsingissä on kouluja, joissa tällaisia oppilaita on yli puolet.

Väestön kielitaitojen moninaistuminen ei kuitenkaan kosketa vain muutamia kaupunkilähiöitä ja niiden kouluja. Myös sellaisten koulujen määrä lisääntyy, joissa vaikkapa 10-50 prosenttia tai vain muutama oppilas puhuu kotona muutakin kuin koulun opetuskieltä. Opetuksessa ei siis voi lähteä siitä, että kaikki oppilaat olisivat ennen kouluikäänsä saavuttaneet suunnilleen samat taidot opetuskielessä tai sosiaalistuneet ensisijaisesti suomenkieliseen kulttuuriin (ks. myös Aalto \& Kauppinen 2011).

Koska sosiaalinen todellisuus on moninainen, moninaisuuden tulisi koulussakin olla lähtökohta eikä poikkeus. Tämä on huomioitu myös opetussuunnitelman perusteissa (POPS 2014), joissa oikeus omaan kieleen ja kulttuuriin määritellään perusoikeudeksi. Opetussuunnitelman perusteiden mukaan "erilaiset identiteetit, kielet, uskonnot ja katsomukset elävät rinnakkain ja ovat vuorovaikutuksessa keskenään" ja "kulttuuritraditioihin tutustutaan, erilaisista ajattelu- ja toimintatavoista keskustellaan rakentavasti ja luodaan uusia tapoja toimia yhdessä". Opetussuunnitelman perusteissa todetaan lisäksi näin: "Jokainen yhteisö ja yhteisön jäsen on monikielinen. Eri kielten käyttö rinnakkain koulun arjessa nähdään luontevana ja kieliä arvostetaan. Kielitietoisessa yhteisössä keskustellaan kieliin ja kieliyhteisöihin kohdistuvista asenteista ja ymmärretään kielen keskeinen merkitys oppimisessa, vuorovaikutuk-

1 Tilastokeskus viittaa termillä vieraskielinen muihin kuin suomen-, ruotsin- tai saamenkielisiin. Termi ei vastaa tämän tutkimuksen eetosta enkä käytä sitä muutoin. 
sessa ja yhteistyössä sekä identiteettien rakentumisessa ja yhteiskuntaan sosiaalistumisessa." Näkemys monikielisyydestä on uudenaikainen: monikielisyys ei tarkoita sitä, että olisi vauvasta saakka kasvanut useamman kielen puhujaksi, vaan globaalissa maailmassa monikielisyys kuuluu jokaisen elämään.

Opetussuunnitelman perusteissa monikielisyyttä ei vain tunnusteta, vaan se otetaan osaksi toimintaa: kulttuureihin tutustutaan, eri kielistä ja kulttuuritraditioista ja niiden merkityksestä keskustellaan, ja luodaan uusia tapoja toimia. Tätä linjausta tukee myös tutkimustieto: monikielisyys koulussa ja erityisesti myös oman muun kuin koulun opetuskielen tukeminen syventää oppimista, vahvistaa kielellistä ja kulttuurista identiteettiä sekä rakentaa yhteisöllisyyttä (ks. esim. Cummins 2000; García 2009; García \& Kleifgen 2018). Tulevaisuuden tärkeitä taitoja on osata toimia yhteisöissä, joiden jäsenillä on keskenään epäsymmetriset kielitaidot. Näitä taitoja on harjoiteltava niin kuin muitakin kieli-, viestintä- ja vuorovaikutustaitoja. Siksi kielitietoinen opetus ja monikielisyyden huomioiminen sen osana eivät koske vain kielellisesti hyvin moninaisia kouluja, vaan kaikkia (ks. Lilja ym. 2017).

Opetussuunnitelma ei kuitenkaan anna opettajille käytännön ohjeita siitä, miten monikielisyyden voi huomioida koulutyössä (ks. myös Kalliokoski ym. 2020). Koulu instituutiona ja luokkahuonetilanteet sen osana on vahvasti rakennettu yksikielisyyden normin varaan, eivätkä kielitietoisen opetuksen periaatteet tai limittäiskieleilyn pedagogiikan edut (ks. luku 3) ole saavuttaneet läheskään kaikkia kouluja ja opettajia. Alisaaren ym. (2019) opettajien kieli-ideologioihin keskittynyt kyselytutkimus paljastaa, että vaikka opettajien suhtautuminen monikielisyyteen on pääasiassa myönteistä, suurta osaa opettajista ohjaa yksikielisyyden normi. Yli kolmasosa vastanneista yli 800 opettajasta on sitä mieltä, että oman kielen käyttö pitäisi aina kieltää oppitunneilla. Lähes neljäsosa kyselyyn vastanneesta on eri mieltä tai vahvasti eri mieltä väitteestä, että on epäeettistä kieltää oppilasta käyttämästä omaa kieltä luokassa. Yli 40 prosenttia opettajista on eri mieltä siitä, että oppilaan pitäisi antaa kirjoittaa omalla kielellään. Kyselyn vastaukset osoittavat myös, että monilla opettajilla ei ole riittävästi tietoa kielen ja identiteetin yhteyksistä tai oman kielen roolista oppimisessa (joissakin väittämissä en osaa sanoa -vaihtoehdon on valinnut yli 20 prosenttia vastaajista). Käytänteiden näkyväksi tekemistä, kehittämistä ja koulutusta siis tarvitaan, sillä opettajat ovat avainasemassa kielitietoisen opetuksen juurruttamisessa (ks. Commins \& Miramontes 2005: 3-102).

Jotta kielellisestä moninaisuudesta tulisi luonnollinen osa jokapäiväistä oppimista ja opetusta, tarvitaan ainakin koulutusta ja pedagogisten käytänteiden kehittämistä sekä keskustelua ideologioista ja asenteista kielivalintojen taustalla. Nämä tarpeet motivoivat Itä-Helsingin uudet Suomen kielet -toimintatutkimushankkeeseen, jonka toteuttivat kielentutkijat, toimittaja ja yhteisötaiteilijat tiiviissä yhteistyössä helsinkiläisen Merilahden koulun oppilaiden ja opettajien kanssa vuosina 2016-2019 (ks. Lehtonen \& Räty 2018; Lehtonen 2019; Lehtonen ym. 2020; Kalliokoski ym. 2020). Hankkeen yleisinä tavoitteina oli tehdä näkyväksi kouluyh- 
teisön kielellistä moninaisuutta, edistää kielitietoutta ja -tietoisuutta sekä kehittää limittäiskieleilyn pedagogisia käytänteitä.

Tämä artikkeli perustuu Itä-Helsingin uudet Suomen kielet -hankkeessa kerättyjen aineistojen (ks. luku 2) analyysiin. Artikkelissa tarkastellaan:

1. miten oppilaat asettuvat kielellisen asiantuntijan rooliin hankkeen työpajoissa

2. miten hankkeen työpajoihin osallistuneet opettajat kokevat ajattelunsa, luokan vuorovaikutuksen tai oppilaiden toiminnan muuttuneen hankkeen myötä.

Ensimmäistä kysymystä käsittelen yhden työpajan tapausesimerkin analyysilla, toista opettajien haastattelujen valossa.

Luvussa 2 kuvaan hankkeen työmuodot, ja metodit sekä artikkelin aineiston. Luvussa 3 määrittelen keskeiset teoreettiset käsitteet: kielellisen asiantuntijuuden, kielitietoisen opetuksen ja limittäiskieleilyn pedagogiikan. Lisäksi avaan koko hankkeen taustalla vaikuttanutta repertuaaripohjaista käsitystä kielitaidosta. Luvut 4 ja 5 koostuvat aineiston analyysista. Luvussa 6 kokoan limittäiskieleilyn tilaa luovia käytänteitä ja pohdin hankkeen vaikuttavuutta.

\section{Aineisto ja metodit}

Itä-Helsingin uudet Suomen kielet -hankkeessa keskeisimpänä toimintamuotona olivat monikielisyyttä näkyväksi tekevät yhteisötaidetyöpajat, joita järjestettiin kolmen vuoden aikana yhteensä yli 40 useille opetusryhmille ja luokka-asteille. Useimmista kerättiin video- ja/tai audioaineistoa. Työpajoissa tehtiin hankkeen toimijoiden (tutkijoiden, yhteisötaiteilijan ja toimittajan) sekä opettajien ja oppilaiden yhteistyönä esimerkiksi kyrillisiä aakkostauluja, arabian aakkosia ja luotiin kielten supersankareita sarjakuvina ja seinämaalauksina (ks. Lehtonen ym. 2020). Työpajoissa keskityttiin kieliin, joiden puhujia opetusryhmissä oli. Koko hankkeen ja tämänkin artikkelin asetelmassa on tärkeää painottaa, että työpajat toteutettiin opetussuunnitelman puitteissa osana tavallisia oppitunteja luokkahuoneissa. Lisäksi aineistoon kertyi kymmeniä oppilaiden ja opettajien haastatteluja hankkeen eri vaiheista.

Hankkeen tavoitteet eivät olleet vain tutkimuksellisia ja tieteelliseen julkaisemiseen tähtääviä, vaan myös taiteellisia, journalistisia, yhteiskunnallisia, ammatillisia ja pedagogisia sekä ennen kaikkea yhteisöllisiä ja tieteen popularisointiin liittyviä. Hankkeessa toimineet tutkijat, yhteisötaiteilijat ja toimittaja ovat työpajojen ja haastatteluaineiston keräämisen lisäksi esimerkiksi pitäneet useita koulutuksia sekä tuottaneet yleistajuista verkkomateriaalia. Tutkijoiden, niin kuin muidenkin osallistujien, ymmärrys aiheesta karttui lukemattomissa kohtaamisissa ja keskusteluissa kolmen vuoden aikana, eikä hankkeessa kerätty tai tuotettu mitään aineistoa vain tiettyä tut- 
kimusartikkelia tai -ongelmaa silmällä pitäen. Siksi fokuksen ja aineiston rajaaminen esimerkiksi tätä artikkelia varten on jonkin verran keinotekoista.

Luvun 4 vuorovaikutusanalyysissa keskityn yhden ryhmän työskentelyyn kyrillisten aakkostaulujen työpajassa. Vuorovaikutusesimerkit on litteroitu (ks. liite) videotallenteelta, jossa tarkastelun kohteena oleva ryhmä on videokameran edessä ja keskiössä. Läsnä tilanteessa ovat koko noin neljän hengen ryhmissä työskentelevä luokka, luokan opettaja sekä työpajaa pitävät hankkeen toimijat. Opettaja ja hankkeen toimijat liikkuvat luokassa vapaasti ryhmästä toiseen. Videoaineisto on rikasta, ja on tutkijan valintaa, mikä siitä päätyy tarkastelun kohteeksi. Tilanne on aineistossa sekä ainutlaatuinen että toistuva: osallistuvan havainnoinnin perusteella tiedän, että kaikissa työpajoissa oppilaat auttoivat luokkatovereitaan ja jakoivat tietoaan omasta kielestään. Jos tarkastelun kohteeksi otettaisiin jokin toinen vastaava tilanne, siitä olisi mahdollista tehdä sekä samansuuntaisia että mahdollisesti juuri kyseiselle tilanteelle ainutlaatuisia havaintoja. Luvun 4 vuorovaikutuskatkelmia voi siis pitää tapausesimerkkeinä siitä, miten oppilaat ottivat asiantuntijan roolin.

Opettajien haastatteluista olen valinnut tarkastelun kohteeksi erityisesti kahden sellaisen opettajan haastattelut, joiden luokkien kanssa teimme yhteistyötä intensiivisesti ja pidempään kuin vain muutaman oppitunnin verran. Tarkastelen luvussa 5 haastattelujen valossa erityisesti sitä, miten työpajat ovat vaikuttaneet opettajan työhön tai luokan vuorovaikutukseen. Vaikka laadullisen tarkastelun kohteena on kaksi opettajaa ja kaksi luokkaa, minulla on muun aineiston ja hankkeen pohjalta käsitys siitä, millainen pajojen vastaanotto yleisesti oli.

Aineiston käsittely tässä artikkelissa on laadullista. Videoaineistoa analyysoidaan on vuorovaikutussosiolinvistisin menetelmin (ks. Lehtonen 2015: 31-35; Rampton 2006). Vuorovaikutussosiolingvistiikassa tarkastellaan usein sitä, miten osallistujat asemoivat itsensä kielen keinoin osaksi meneillään olevaa vuorovaikutustilannetta ja suhteessa muihin osallistujiin tai esimerkiksi tilanteessa relevantteihin voimasuhteisiin (Lehtonen 2015: 56-57). Tarkastelemalla jaksoja, joissa kieli itsessään nousee huomion, toiminnan tai metakielellisen kommentoinnin kohteeksi, voidaan valottaa kieli-ideologioita ja kielikäsityksiä (Lehtonen 2015: 35-46).

Tutkimustani voi luonnehtia lingvistiseksi etnografiaksi ja toimintatutkimukseksi. Etnografian piirteitä ovat esimerkiksi pitkä oleskelu kentällä ja pyrkimys ymmärtää osallistujien vuorovaikutusta heidän omista lähtökohdistaan sosiaaliseen kontekstiin tutustuen, sekä monenlaiset kumuloituvat aineistonkeruun tavat, kuten havainnointi, haastattelut, ääni- ja videotallenteet, valokuvat ja muistiinpanot. Lingvistinen etnografia (ks. esim. Lehtonen \& Pöyhönen 2020; Rampton ym. 2015) on tutkimussuuntaus, joka tutkii usein kieli-ideologioiden materialisoitumista vuorovaikutuksessa, erityisesti konteksteissa, joihin liittyy epäsymmetrisiä valta-asetelmia. Lingvistinen etnografia on tässä tutkimuksessa keskeinen viitekehys, sillä kyse on nimenomaan kielten keskinäisestä valta-asemasta, eri kieliin liittyvistä arvotuksista sekä kielten käyttöön ja niiden rajojen ylittämiseen liittyvistä sosiaalisista nor- 
meista koulun ja luokkahuoneen institutionaalisessa kontekstissa. Rehtorien, opettajien ja muiden auktoriteettien valinnoilla on suuri vaikutus siihen, miten koulun monikielisyys näkyy ja otetaan huomioon koulun tiloissa. Kuten Alisaaren ym. (2019) tutkimuksestakin ilmenee, ei ole tavatonta, että muiden kuin opetuskielen käyttöä rajoitetaan koulussa tai ettei limittäiskieleilyn käytänteitä tai niiden etuja tunneta riittävästi. ${ }^{2}$ Opettajat voivat myös kokea riittämättömyyttä keinoissaan toteuttaa monikielisyyttä, vaikka suhtautuisivatkin siihen myönteisesti (Suuriniemi ym. tässä teoksessa).

Toimintatutkimuksen luonteeseen kuuluu, että tutkijat eivät ole vain havainnoijia ja tilanteiden analysoijia ja kuvaajia, vaan toimivat yhdessä muiden osallistujien kanssa yhteisesti sovittujen päämäärien saavuttamiseksi. Siksi Itä-Helsingin uudet Suomen kielet -hanke toteutettiin yhdessä opettajien ja oppilaiden kanssa. Tarkoituksena on luoda uusia toimintatapoja ja mahdollisesti muuttaa yhteisön toimintakulttuuria pitkälläkin aikavälillä. (Ks. McNiff 2013.) Yhdessä luodut toimintatavat siis jäävät yhteisöön vielä senkin jälkeen, kun tutkimus loppuu. Toimintatutkimuksen keinoin on mahdollista yhdistää opetussuunnitelman perusteiden abstraktit askelmerkit, ammattitaitoisten opettajien omiin tarpeisiinsa kehittämät kielitietoiset käytänteet ja tutkijoiden teoriat monikielisyyden merkityksestä identiteetille ja oppimiselle ja tehdä teoriasta käytäntöä (vrt. esim. Winkler 2007; Coles-Ritchie \& Lugo 2008; French \& Armitage 2020; Nugent 2020).

\section{Keskeisiä käsitteitä}

\subsection{Repertuaari ja asiantuntijuus}

Itä-Helsingin uudet Suomen kielet -hankkeen työpajoissa asiantuntijan rooli muotoutui keskeiseksi pedagogiseksi työkaluksi. Annoimme työpajan keskiössä olevan kielen taitajille erityisaseman: kerroimme, että he saavat toimia asiantuntijoina. Tässä artikkelissa luvun 4 analyysi valottaa tilannetta, jossa oppilas asettuu tähän rooliin. Asiantuntijuudessa ei ole kyse vain koululaisiin vetoavasta kielikuvasta, vaan taustalla on Ramptonin (1995) käsitteistys, jossa abstraktin natiivipuhujan käsitteen sijaan kielten taitoa ja tietoa niistä kuvataan asiantuntijuutena (expertise). Asiantuntijuus on osittaista: kukaan ei hallitse kaikkia yhteen kieleen liitettyjä resursseja. Toisin kuin

2 Olen muun muassa koulutuksiin osallistuneilta opettajilta vielä aivan viime aikoinakin kuullut myös kouluista, joissa muiden kuin suomen kielen käyttö on pyritty kieltämään myös välitunneilla. Tällöin kyse on hyvin vahvasta yksikielisyyden ideologiasta ja normista institutionaalisessa tilassa. Mielestäni on selvää, ettei tällainen käytäntö ole opetussuunnitelman perusteiden eikä yksilön kielellisten oikeuksien mukainen eikä perusteltu. 
natiivipuhujan käsite, asiantuntijuus korostaa lisäksi sitä, että asiantuntijuutta voi kartuttaa myöhemminkin elämässä, ja se tunnustaa, että pienikin asiantuntijuus on jo kielitaitoa, jota voi hyödyntää. Kielen voi ottaa käyttöön, vaikkei sitä ei osaisi "kokonaan" tai "täydellisesti".

Edellä kuvattu kielinäkemys istuu repertuaaripohjaiseen käsitykseen kielitaidosta (Blommaert \& Backus 2012; Busch 2015; Dufva 2020). Repertuaarin käsite kuvaa kielitaidon kokoelmana erilähtöisiä aineksia, joita puhuja on elämänsä aikana kerännyt ja omaksunut. Erilähtöinen tarkoittaa, että repertuaarin ainekset assosioituvat eri rekistereihin (Agha 2007; Lehtonen 2015: 46-50). Rekisterit ovat toiminnan malleja, joihin liitetään kielellisiä ja muita semioottisia resursseja. Resursseilla tarkoitetaan tässä kielenpiirteitä tai muita vuorovaikutuksen keinoja, joilla on mahdollista luoda merkitystä ja osallistua meneillään olevaan toimintaan ja ilmaista asennoitumista siihen (Lehtonen 2015: 38; Lehtonen \& Pöyhönen 2020; ks. myös Dufva 2020).

Keskeistä repertuaaripohjaiselle kielitaitokäsitykselle on, että kenenkään kielitaito ei koostu kokonaisista ja keskenään täysin samanlaisista rekistereistä, vaan olemme oppineet käyttämään sopiviin rekistereihin assosioituvia resursseja niissä tilanteissa, joissa olemme niitä tarvinneet (Lehtonen 2015: 301-302; Dufva 2020). Rekistereitä ovat vakiintuneet kielet, esim. suomi, venäjä, somali, mutta myös vaikkapa hip hop -tyyli tai opetuspuhe (ks. myös Madsen ym. 2015). Koulun ja luokkien institutionaalisen tilan kannalta tämä tarkoittaa, että suomen kieleen ja suomalaisen koulun opetuspuheen rekistereihin liitetyt resurssit ovat vanhastaan olleet käytössä, ja osa oppilaiden repertuaareista on jäänyt katveeseen tai jopa näkymättömiin. Hankkeen yhtenä tavoitteena on tehdä näkyväksi oppilaiden repertuaarien moninaisuutta. Tämä edellyttää kuitenkin muutosta siinä, mitkä resurssit koetaan koulun institutionaalisiin tiloihin ja toimintoihin kuuluviksi: Aghan (2007) termein kyse on eri (kielten) resurssien rekisteriytymisestä luokkahuoneen rekistereihin.

\subsection{Kielitietoinen koulu ja limittäiskieleilyn pedagogiikka}

Sekä kielitietoisen opetuksen että limittäiskieleilyn pedagogiikan keskeiset periaatteet tiivistyvät mielestäni lausahdukseen "Kaikki kielet ovat oppimisen kieliä" (Commins 2019). Kielitietoisessa opetuksessa huomioidaan, että kieli on olennainen osa kaikkea oppimista: kun opimme sisältöjä, opimme aina myös kieltä, jolla niistä puhutaan (ks. myös Aalto \& Kauppinen 2011). Näin kaikki opettajat ovat oman alansa kielen opettajia, mikä on nostettu kielitietoisen koulun tunnuslauseeksi (vrt. García \& Sylvan 2011).

Kielitietoinen opettaja tietää, että oppimisen ei tarvitse tapahtua vain koulun opetuskielellä. Jos oppilas osaa vaikkapa arabiaa, kiinaa tai venäjää, hän voi oikein hyvin hakea tietoa tai keskustella opiskeltavasta asiasta näillä kielillä. Oppilaiden repertuaarien epäsymmetrisyyden huomioiminen ja oman kielen käyttö koulutyössä 
syventävät oppimista, vaikuttavat oppilaan minäkuvaan ja kohottavat motivaatiota (Cummins 2000, 2018; García \& Sylvan 2011; García \& Kleifgen 2018; Prediger \& Wessel 2013). Opettaja ei välttämättä tällöin aina ymmärrä, mitä oppilas sanoo, lukee tai kirjoittaa, ja hänen on tältä osin luovuttava kontrollista ja luotettava oppilaan asiantuntijuuteen omassa kielessään.

Siinä missä kielitietoinen opetus korostaa kielen merkitystä kaikessa oppimisessa, limittäiskieleilyn pedagogiikka on keskittynyt erityisesti monikielisiin oppimisympäristöihin, ja siinä eri kielet tietoisesti valjastetaan palvelemaan oppimista (translanguaging pedagogy, García \& Li 2014; Svensson \& Torpsten 2017; García ym. 2017). Limittäiskieleily-termin perusosana on kieleily (engl. languaging, ks. lisää Lehtonen 2015: 52-54; Madsen ym. 2015; vrt. Li 2018: 17-19). Kieleilyn käsite korostaa kieltä toimintana sen sijaan, että kieltä tarkasteltaisiin "oliona" tai staattisena järjestelmänä. Translanguaging on kuitenkin osittain kieleilyn teoriasta erillään kehittynyt teoreettinen suuntaus (ks. Lewis ym. 2012; vrt. Li 2018), jota hyödynnän lähinnä pedagogisena työkaluna. Olen aiemmin suomentanut languaging-termin kieleilyksi ja käytän translanguaging pedagogy -sanaliitosta nyt johdonmukaisesti käännöstä limittäiskieleilyn pedagogiikka.

Limittäiskieleilyn pedagogiikka juontaa juurensa Walesiin, jossa koulukieli on englanti ja vähemmistökieli kymri ja suuri osa oppilaista puhuu kotona vähemmistökieltä (Lewis ym. 2012). Limittäiskieleilyn pedagogiikassa trans-etuliite kuvaa toisaalta sitä, että sisältöjä opitaan yli kielirajojen ja kielten välillä, ikään kuin kielirajojen tuolla puolen (Lewis ym. 2012.; García \& Li 2014; Li 2018). Toisaalta trans-etuliite kuvaa limittäiskieleilyn pedagogiikan muutosvoimaa: sen avulla on mahdollista neuvotella niistä sosiaalisista normeista, jotka ohjaavat kielenkäyttöämme (García 2009; García \& Kleifgen 2018; Creese \& Blackledge 2015; Li 2018).

Suomalaistakin koulua on ohjannut yksikielisyyden normi (ks. Jørgensen 2008; Alisaari ym. 2019): esimerkiksi arabia tai somali eivät juuri ole kuuluneet suomalaiseen koululuokkaan (Tarnanen ym. 2017; vrt. Møller 2015, 2019; Lehtonen \& Møller tekeillä). Opettajan on pedagogisin keinoin vähitellen muokattava luokan vuorovaikutusta niin, että muut kuin opetuskieli limittyvät toimintaan ja oppimiseen luontevasti. Li (2018: 23-24) on käyttänyt käsitettä limittäiskieleilyn tila (translanguaging space), jossa on mahdollista työstää sosiaalisia normeja niin, että aiemmin eri yhteyksiin kuuluneet resurssit ja rekisterit kohtaavat limittäiskieleilyn tilan käytänteissä. Kun opetustilanteessa vallitsee limittäiskieleilyn tila, oppimisessa voidaan ylittää kielten sosiaaliset rajat ja rajoitukset. 


\section{Oppilaan kielellinen asiantuntijuus osana työskentelyä}

Tässä osiossa erittelen kolmen vuorovaikutuskatkelman avulla (1-3), miten työpajoissamme luotiin luokkiin limittäiskieleilyn tilaa, jossa oppilaat saattoivat hyödyntää omaa kielellistä asiantuntijuuttaan. Katkelmat ovat samalta oppitunnilta kyrillisten aakkosten työpajasta, ja oppilas (Adam ${ }^{3}$ ) asemoituu asiantuntijaksi suhteessa oppilaisiin, tutkijoihin ja opettajaan. Niin kuin toimintatutkimuksessa yleensä, myös meidän hankkeessamme keskeistä oli opettajan, tutkijan ja oppilaan roolien hetkittäinen sekoittuminen: kun näkee itsensä tai muut tavallisuudesta poikkeavassa roolissa, todellisuudesta saa rikkaamman kuvan.

Kun aloimme työstää kyrillisiä tai arabian aakkosia uuden luokan kanssa, tavallisesti aluksi näytimme aakkosten kuvan luokalle ja kysyimme, kuka tunnistaa aakkoset ja osaako joku jotakin sellaista kieltä, jota kirjoitetaan näillä aakkosilla. Näin esimerkiksi arabian- ja venäjänkieliset oppilaat saivat itse määritellä suhteensa kieliin. Aina joku ilmoittautui. Voi ajatella, että operationalisoimme sosiolingvistisen kielellisen asiantuntijuuden käsitteen pedagogiseksi työkaluksi. Ketään ei pakotettu tähän rooliin, mutta oppilaat asettautuivat siihen mielellään. Useimmissa työpajoissa panin merkille, että muut oppilaat myös alkoivat nopeasti kohdella heitä oman kielensä asiantuntijoina ja kysyivät siihen liittyvissä kysymyksissä apua ensisijaisesti asiantuntijaoppilailta opettajan tai tutkijoiden sijaan.

Esimerkissä 1 Adam auttaa Zhugria kirjoittamaan venäjänkielisen sanan шина 'autonrengas' aakkostauluunsa.

$(1)^{4} \quad$ Kyrillisten aakkosten työpaja

Zhugri $=$ Zh; Adam = A; HL = Heini Lehtonen; RR = Reetta Räty (hankkeen toimittajajäsen)

$01 \mathrm{Zh}$ kirjotaks mä sen (nimen) tähä.

$02 \mathrm{~A}$ ai- ((nousee))

$03 \mathrm{Zh}$ tähä.

$04 \mathrm{~A}$ anna. ((ottaa kynän Zhugrilta,

$05 \quad$ kirjoittaa suttupaperille sanan))

$06 \quad(($ Zh ottaa kynän ja alkaa kirjoittaa

07 aakkoskuvaan))

$08 \mathrm{~A}$ kirjota toi š. ((Ш))

3 Aineistossa esiintyvien oppilaiden nimet on muutettu ja opettajaan viitataan vain "opena".

4 Käsittelen esimerkkejä 1-3 myös tekeillä olevassa artikkelissani Linguistic expertise and (trans)languaging space in a school class. Examples from a sociolinguistic action research project. 


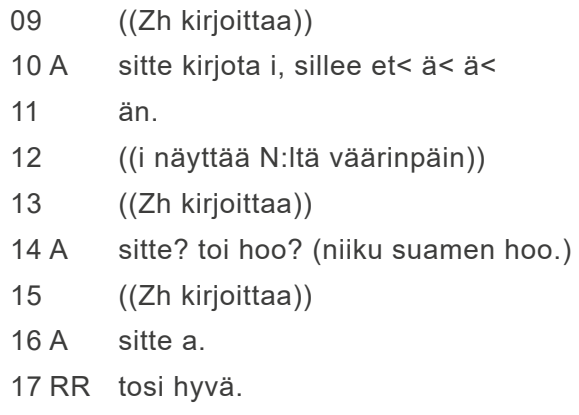

Adam ottaa aktiivisesti asiantuntijan roolin: hän reagoi Zhugrin kysymykseen (rivit 01-02), nousee ylös ja menee hänen luokseen. Voi sanoa, että Adam toimii opettajana ja tekee jopa pedagogisia valintoja: sen sijaan, että hän esimerkiksi itse kirjoittaisi sanan kuvaan, hänen tavoitteenaan on tukea Zhugria tehtävässä niin, että Zhugri tekee sen itse. Hän kirjoittaa sanan malliksi paperilapulle (rivit $04-05$ ) ja auttaa Zhugria vertaamalla kirjaimia latinalaisiin aakkosiin, jotka he molemmat tuntevat (rivit 10 - 12, 14). Tässä Adam osoittaa kielellistä tietoisuutta ottamalla käyttöön kielirajat ylittävän limittäiskielisen kompetenssin: hän pystyy asettumaan Zhugrin asemaan ja ottamaan huomioon sen, mikä on heille yhteistä tietoa, mutta samaan aikaan jakamaan omaa asiantuntijuuttaan. Näin toteutuu yksi hankkeen ja työpajojen keskeisistä tavoitteista, ja hankkeen toimittajajäsen (RR) antaakin Adamille positiivista palautetta (rivi 17).

Seuraava katkelmat osoittavat, että Adam ei asemoidu asiantuntijaksi pelkästään suhteessa vertaisiinsa vaan myös hankkeen tutkijoihin ja toimittajajäseneen (2) sekä opettajaan (3). Esimerkissä 2 Adam neuvoo toimittajaa (RR) шина -sanan ääntämisessä. Aloitteen tekee toimittaja: hän asettaa itsensä oppijan ja oppilaan asemaan ja asemoi Adamin asiantuntijaksi kysymällä, miten sana äännetään (rivi 20). Kun RR ääntää sanan (rivi 23), Adam ei olekaan tyytyväinen vaan kiinnittää huomiota sanan ensitavun vokaalin laatuun. Ääntämiseen keskitytään niin kauan, että RR ymmärtää, mitä hänen olisi korjattava (rivit 34-39).

(2) Kyrillisten aakkosten työpaja

Zhugri = Zh; Adam = A; HL = Heini Lehtonen; RR = Reetta Räty (hankkeen toimittajajäsen)

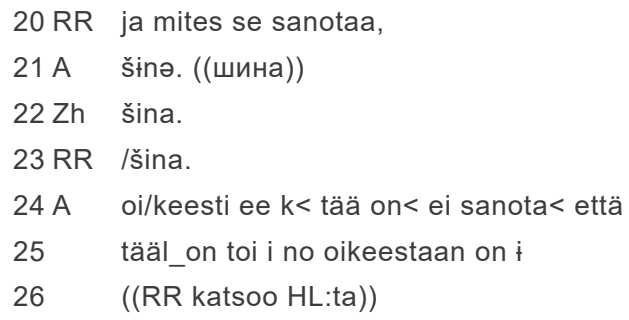




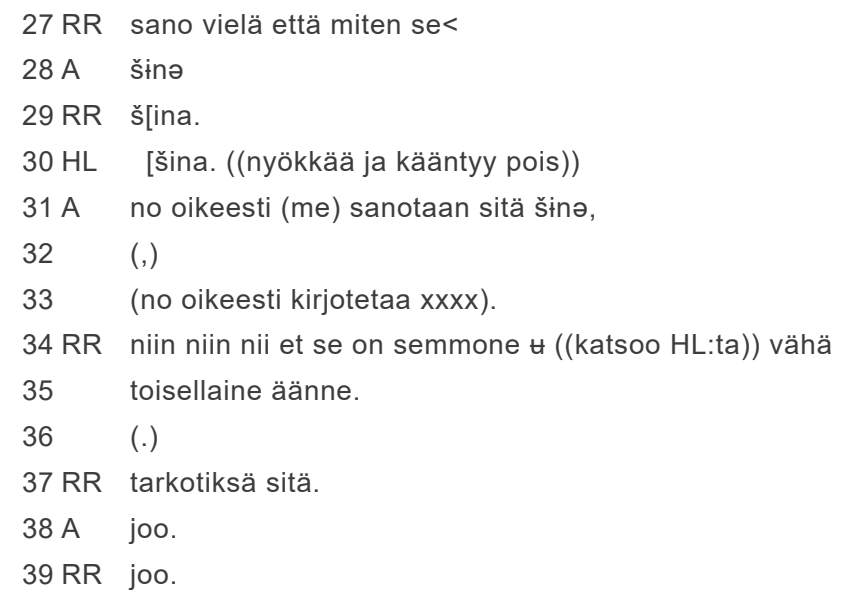

Katkelmassa 2 huomioni kiinnittyy ainakin kolmeen seikkaan. Ensinnäkin se osoittaa, että viidesluokkalainenkin pystyy kiinnittämään huomiota hyvin spesifiin kielenpiirteeseen, kuten vokaalin laatuun, ja vieläpä sanallistamaan huomionsa. Toiseksi Adam osoittaa kielitietoisuutta niin, että hän pystyy asettumaan venäjää taitamattoman suomenkielisen asemaan. Olemme juuri oppineet, että venäjän $и$ ääntyy niin kuin suomen i, mutta tässä sanassa i ääntyykin takaisempana (ł). Adam osaa ajatella, että suomenkielinen RR korvaa takaisemman i-äänteen suomen /i/:llä ja kiinnittää RR:n huomion juuri tähän seikkaan (24-25, 31, 33). Kolmanneksi Adam täyttää asiantuntijan roolin ja ottaa sen omakseen: hän ei tyydy siihen, että RR lausuu sanan jotenkuten, vaan ottaa tehtäväkseen korjata ääntämystä ja auttaa RR:ä ymmärtämään, missä hän tekee virheen. Näin lopulta käykin (rivit 34 - 39). Vaikka RR yrittää etsiä apua myös kielentutkijalta (HL) (rivi 34), tältä ei tule apua, vaan asiantuntijaksi asemoituu nimenomaan Adam.

Viimeisessä katkelmassa 3 Adam saa kiitosta asiantuntijuudestaan ja asiantuntijan roolin hyvästä hoidosta. Siinä hän lisäksi asemoituu asiantuntijaksi myös suhteessa opettajaan.

(3) Kyrillisten aakkosten työpaja

Zhugri = Zh; Adam = A; HL = Heini Lehtonen; RR = Reetta Räty (hankkeen toimittajajäsen);

OPE = luokan opettaja

40 OPE (osaaksä sanoos sen.)

$41 \mathrm{Zh} \quad(x x x x)$

42 OPE mikä.

$43 \mathrm{Zh}$ šina.

$44 \quad(($ Adam toistaa sanaa hiljaa. $))$

45 OPE hyvä. (.) šina. 


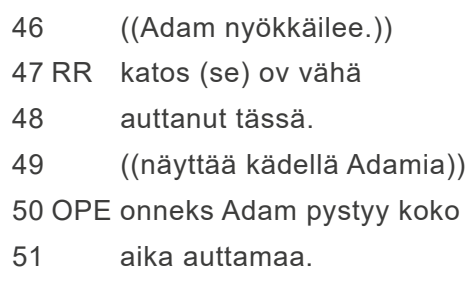

Kun opettaja tulee katsomaan, mitä ryhmä on saanut aikaan, hän kysyy, osaako Zhugri ääntää kirjoittamansa sanan. Zhugri osoittaa oppineensa sen (rivit 40-43). Adam ei kuitenkaan kokonaan väisty asiantuntijan tai opettajan roolista: hän valvoo ja arvioi ääntämistä ja hyväksyy sen nyökkäilemällä (rivit 44, 46).

Onkin kiinnostavaa tarkastella sitä, miten opettaja asemoi itsensä tietämättömäksi osallistujaksi (knowing participant vs. unknowing participant, Goodwin 1979) ja oppijaksi luopumatta täysin opettajan auktoriteetista. Opettajan kysymys osaaksä sanoo sen ei ole siinä mielessä täysin tyypillinen opettajan luokkahuonekysymys, että opettaja ei tiedä vastausta eikä hän itse osaa lukea sanaa. Rivin 45 vastaus on kaksiosainen: alkuosa hyvä on tyypillinen opettajan evaluoiva vuoro, joka on osa luokkahuoneen klassista IRE-sekvenssiä (initiation - response - evaluation; ks. Tainio 2007). Evaluaatio hyvä koskee Zhugrin toimintaa $(41,43)$, johon opettajan initiaatio (rivit 40,42) kutsui. Sen sijaan vuoron toinen osa, jossa opettaja toistaa itselleen vieraan sanan, kääntääkin roolit päinvastoin: Zhugri on tietävä osallistuja (Goodwin 1979), joka jakaa tietonsa opettajalle. Evaluaation opettajan ääntämiselle esittää Adam nyökkäilemällä (rivi 46). Venäjänkielisestä sanasta on ainakin hetkellisesti tullut paitsi Adamin, myös Zhugrin ja muiden osallistujien yhteistä omaisuutta. Adam saa sekä opettajalta että hankkeen edustajalta positiivista palautetta asiantuntijana toimimisestaan (rivit 47-51), mikä osoittaa, että hänen toimintansa on ollut oppitunnin yhteisen agendan mukaista.

Näiden katkelmien valossa näyttää siltä, että työpajoissa on onnistuttu sekä hankkeen että opetussuunnitelman tavoitteissa: Roolien ravistelun myötä sekä oma että muiden asiantuntemus ja kielelliset taidot on tunnistettu. Kielitietoisuutta ja -tietoa on käytetty ja kasvatettu, ja monikielisyydestä on tullut jaettua ja tila on avattu limittäiskieleilylle.

\section{Opettaja limittäiskieleilyn tilan luojana}

Yhteistyökoulussamme oli jo ennen hankkeemme alkua luotu kielitietoisia käytänteitä ja tehty monikielisyyttä näkyväksi. Koulussa esimerkiksi toimi kielitietoisuuteen keskittyvä työryhmä, ja oppilaiden kanssa oli tehty monikielinen satukirja, johon oli koottu tarinoita oppilaiden omilla kielillä sekä suomeksi. Koulu on ollut monikielinen ja -kulttuurinen jo kymmeniä vuosia, ja opettajat ovat opetustyössään luoneet 
monikielisyyttä hyödyntäviä käytänteitä. Toimintatutkimushankkeessamme yksi keskeisistä tutkijan rooleista olikin sanoittaa ja käsitteellistää opettajien hiljaista tietoa ja tehdä käytänteitä näkyväksi. Joskus opettajat keskustelujen seurauksena huomasivat tulleensa tietoisemmiksi monikielisten opetusryhmien opettamiseen liittyvästä ammattitaidostaan ja käytänteistään. He esimerkiksi kuvaavat haastatteluissa, että oppilaat hakevat tietoa tai keskustelevat omista asioista omilla kielillään (ks. myös Kalliokoski ym. 2020). Kuten Alisaaren ym. (2019) tutkimuksesta ilmenee, tällaisetkaan käytänteet eivät kaikissa kouluissa kaikille opettajille ole tuttuja (vrt. Tarnanen ym 2017).

Hiljaisesta tiedosta ja aiemmista monikielisistä käytänteistä huolimatta hankkeen työpajoihin osallistuminen muutti opettajien ajattelua ja vaikutti pedagogisiin käytänteisiin ja luokkien toimintaan. OPE1 kuvaa haastatteluesimerkissä 4 sitä, miten hankkeeseen osallistuminen on muuttanut hänen toimintaansa opettajana ja millaisia vaikutuksia sillä on ollut luokan työskentelyyn.

(4) Viidennen luokan opettajan (OPE1) haastattelu

Haastattelijana $\mathrm{HL}$. Lihavoinnit $\mathrm{HL}$.

OPE1 - - mutta ja ja mä oon enemmän ollu kans sitä (.) se on johtunu mun tietämättömyydestä että että et nyt sitä suomea suomea suomea? (.) mut nyt ku te ootte tuonu esiin näit kansainvälisii tutkimuksii ja muita että .hhh omaa äidinkieltä voi enemmänki hyödyntää kuitenkin (.) et se päinvastoin tukee sitä (.) *mt niin tää tieto .hhh on tehny sen että mä nyt (.) nyt niinku käytän sitä myös oppitunneilla paljon enemmän ja (.) se on ollu ehdottomasti (.) niinku mielettömän hyödyllistä .hh et he ovat motivoituneempia ja nimenomaan valmistavan luokan oppilaiden (.) .h öö (.) inttegraatios mä jopa kutsun inkluusioksi koska se on joka aa[must kel]lo kymmenestä

$\mathrm{HL}$ [\#mm\# ]

OPE1 eteenpäin et nyt ku on isommat oppilaat pitkää päivää niin .hh niin heidän niinku se motivaatio on olla täällä \#tunneilla\# .h ja::

ja:: lisäksi et miten oppilaat niinku uuden opetussuunnitelman mukaan muutenkin opiskelevat enemmän yhdessä auttavat toisiaan ja nyt kun pystyy käyttää sitä omaa kieltä (.) .hh joka on rikkaus tässä lu- luokassa koska tässä on monta kieltä (.) ja he pystyvät tosiaan auttamaan toisiaan (.) .h kun tulee valmistavan luoka oppilaita tähän? *mt että \#mm\# .h et tää on ollu niinku (.) mh mielettömän hyvä ja m- mä niinku jopa ajattelen niitä että \#ee\# niin paljon mä oon saanu tästä et siihen vanhaan mä en 


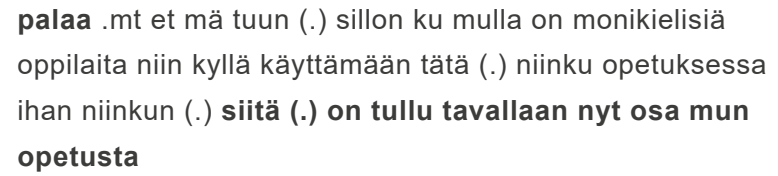

OPE1 tuo esiin, että aiemmin hän oli epävarma siitä, miten omia kieliä kannattaa ottaa huomioon opetuksessa, koska tiedosti velvollisuutensa opettaa oppilaitaan toimimaan suomeksi. Kouluttaessani opettajia olen havainnut, että tällainen "hyvää tarkoittava yksikielisyyden normi" ohjaa monia opettajia: opettajat vilpittömästi uskovat toimivansa oppilaiden hyväksi keskittymällä pelkästään suomen kielen käyttöön. OPE1 painottaa tutkimustiedon merkitystä. Tutkijoiden välittämä tieto oman kielen merkityksestä oppimisessa vakuutti opettajan siinä määrin, että hän uskalsi muuttaa toimintaansa. Muutos on siis saavutettu opettajan ja tutkijoiden yhteistyöllä.

OPE1 kuvaa kielitietoisten ja limittäiskieleilyn käytänteiden positiivisia vaikutuksia: hänen mielestään oppilaat ovat motivoituneempia, erityisesti ne, jotka ovat oppineet suomea vasta verrattain vähän aikaa. Opettaja on myös huomannut, että oppilaat auttavat enemmän toisiaan. OPE1:n luokka oli kaikista luokista eniten yhteistyössä hankkeen kanssa, ja vaikuttaa siltä, että oppilaat ovat tunnistaneet omat ja toistensa kielelliset taidot ja ottaneet ne käyttöön osana oppimista ja luokan institutionaalista vuorovaikutusta. Hankkeeseen osallistuminen on ollut OPE1:n opettajuuden kannalta jopa mullistava: hän sanoo painokkaasti, ettei palaa vanhaan ja että kielitietoisista käytänteistä on tullut osa hänen opetustaan.

OPE2:n kolmannen luokan kanssa hankkeessa tehtiin seinämaalaus, joka koostui "kielten haltioista" ja monikielisestä runosta, jonka laadinnassa lapset toimivat asiantuntijoina. Moni näki ensi kertaa omaa kieltään kirjoitettuna koulun tilassa, koulutyön puitteissa. OPE2 kuvaa hankkeeseen osallistumisen vaikutuksia esimerkissä 5 (ks. myös Kalliokoski ym. 2020).

(5) Kolmannen luokan opettajan (OPE2) haastattelu seinämaalausprojektin jälkeen Haastattelijoina Reetta Räty ja Heidi Niemelä.

OPE2 niin niin jotenkin sit se on painottunu semmoseen et joo että (.) he on ollu niinku englannin kielen taidosta tai ranskan kielen taidosta niin niist aika ylpee (0.5) ja sitte (.) no suomi on tietty ollu siitä ei oo ehkä hirveesti puhuttu kun se on jotenkin niinku (.) itsestäänselvyys tääl (.) äähm mut sitten nyt ne on ollu (.) kyl tosi ylpeitä siitä ihan omast kielestään mikä on tosi hienoo ja sit myös (.) ne on alkanu enemmän käydä niil oman kielen tunneilla (.) että $n$ : et siitä mä oon puhunu tosi (.) paljon (.) vanhemmille et kuinka tärkeetä se olis just sen käsitteellisen ajattelun (.) ääh (.) takia (.) ja (.) mut sit jotenkin nää lapset ite ei oo siit $n$ - iin innostunu mut nytte just esimerkiks (.) arabiaan ni sinne meni sit ainakin kolme sen projektin jälkeen ne sit ilmottautu et he haluukin (.) joo 
(.) joo (.) et ihan (.) ehdottomasti oli semmonen voimauttava (.) projekti tai jotenkin et heil on jotain semmosta niinku ittellä ((naurahtaa)) mitä sitä taas niinku

(.) n: tai todella joku semmonen v- voima

OPE2:n mukaan hanke oli voimauttava ja muutti oppilaiden suhtautumista omaan kieleensä (ks. myös Kalliokoski ym. 2020): OPE2 on havainnut ylpeyttä omasta kielestä, ja muutos suhtautumisessa näkyy konkreettisesti niin, että osa oppilaista on hankkeen jälkeen suhtautunut kiinnostuneemmin ja myönteisemmin oman kielen opetukseen. Oman kielen merkitys osana koulutyötä ja oppimista on siis kirkastunut. OPE2:n huomio siitä, että esimerkiksi ranskan tai englannin taidosta on oltu ylpeitä aiemminkin, paljastaa sen, miten eri tavalla eri kieliä ja niiden taitoa arvotetaan ja arvostetaan: englannin tai muiden suurten länsimaisten kielten taito ja opiskelu näyttäytyy tavoiteltavana, kun taas esimerkiksi arabian tai somalin kielen taito saattaa koulussa jäädä kokonaan piiloon. Englannin tai ranskan opiskelu tai käyttö kuuluu luontevasti kouluinstituution rekistereihin, arabian- tai somalinkielinen "oppineisuus" taas ei.

Seinämaalausprojektin alussa oli selvää, että lapset eivät olleet tottuneet jakamaan oman kielensä resursseja luokassa, vaan he ujostelivat ja tarvitsivat paljon rohkaisua - ja siitä huolimatta moni pitäytyi suomessa tai englannissa. Hankkeen lopuksi yksi lapsista tokaisi, että jos nyt pyytäisimme sanomaan oman kielen sanoja, he olisivat paljon rohkeampia. Mitä siis oli tapahtunut? Muutosta voi käsitteellistä ajatuksella tiettyyn tilaan liittyvistä käytänteistä ja niiden luomista normeista.

Aiemmin koulujen oppimisympäristöjen institutionaalisessa tilassa oli vallalla yksikielisyyden normi: suomen kieli oli luonnollistunut valinta opetustilanteiden ja luokkahuoneen vuorovaikutuksessa. Tätä luonnollisuutta kuvaavat haastatteluissa sekä OPE1 (mä oon enemmän ollu kans sitä (.) se on johtunu mun tietämättömyydestä että että et nyt sitä suomea suomea suomea?) että OPE2 (no suomi on tietty ollu siitä ei oo ehkä hirveesti puhuttu kun se on jotenkin niinku (.) itsestäänselvyys tääl). Tämä ei tarkoita sitä, että opettajat olisivat suhtautuneet monikielisyyteen kielteisesti, eikä edes sitä, että omaa kieltä ei olisi lainkaan saanut luokkahuoneessa puhua. Kyse on siitä, että kaikki kielet eivät yhtä luontevasti kuulu tai ole kuuluneet suomalaisen kouluinstituution ja luokkatilan vuorovaikutuksen rekistereihin. Hankkeen toimintatavoille on keskeistä, että eri kielten asiantuntijuudesta tulee yhteisten tavoitteiden - seinämaalauksen, aakkostaulujen - onnistumisen tae, mikä tekee kielten asiantuntijuudesta osaamisen arvoista. Oppilaat huomaavat, että kielet näkyvät ja kuuluvat tilassa, johon aiemmin on kuulunut vain suomi. Luokkahuoneen ja koulun institutionaalinen tila muuttuu vähitellen yksikielisestä limittäiskieleilyn tilaksi.

Institutionaalinen tila ei muutu yksikielisestä limittäiskieliseksi itsestään, vaan opettajan on muutettava omaa toimintaansa. Koulun ja luokkahuoneen institutionaalinen limittäiskielinen tila luodaan pedagogisilla käytänteillä. Hankkeessa kehitetyt käytänteet eivät ole ainoa mahdollinen tie limittäiskieliseen tilaan, mutta ne 
KIELITAITOJEN KIRJO KÄYTTÖÖN,

LIMITTÄISKIELEILYÄ LUOKKAAN

luovat ymmärrystä siitä, mitä muutos vaatii: oppimistehtäviä, joihin tarvitaan oppilaiden koko kielitaitoa ja jotka nostavat kielet näkyviin ja kuuluviin koulun ja luokkahuoneen tilaan koulukielen rinnalle.

\section{Lopuksi: yksikielisyyden normista limittäiskieleilyn tilaan}

Olen tässä artikkelissa analysoinut Itä-Helsingin uudet Suomen kielet -hankkeen työpajojen vuorovaikutusta yhden tapausesimerkin valossa ja hankkeen vaikutuksia kahden opettajan haastattelun pohjalta. Analyysi tarjoaa ratkaisuja ja oivalluksia, jotka voivat auttaa ja kannustaa muokkaamaan opetusta kielitietoisempaan suuntaan ja luomaan opetustilanteisiin limittäiskieleilyn tilaa, jossa oppilaiden koko kielellinen repertuaari on käytössä.

Luokkahuoneen institutionaalinen vuorovaikutus, jota on ohjannut yksikielisyyden normi, muuntuu limittäiskieleilyn tilaksi vain, jos opettaja muuttaa omaa toimintaansa, sillä opettajan pedagogiset valinnat luovat raamit odotuksenmukaisille sosiaalisille normeille (ks. myös Kalliokoski ym. 2020). Analyysini ja hankkeen kokemusten perusteella kielitietoisia ja limittäiskieleilyyn kannustavia oppimistehtäviä tai pedagogisia käytänteitä voi luonnehtia seuraavasti:

- Oppilaat saavat itse määritellä asiantuntijuutensa ja suhteensa kieliin ja identiteetteihin: oppilaille tarjotaan mahdollisuus asettua asiantuntijan rooliin mutta kenenkään asiantuntijuutta tai kielellistä identiteettiä ei oleteta ilman omaa ilmoitusta.

- Kielitietoinen opetus ja limittäiskieleilyn pedagogiikka eivät ole poikkeuksia tai erityisjärjestelyitä vaan opetussuunnitelman mukaista opetusta, osa jatkuvaa kouluarkea ja osa normaaleja oppitunteja.

- Tehtävät on pedagogisesti suunniteltu niin, että niiden onnistunut suorittaminen edellyttää vuorovaikutusta ja yhteistyötä, jossa on hyötyä kaikenlaisesta kielellisestä ja muusta - myös luokkahuoneen ulkopuolella hankitusta -asiantuntijuudesta.

- Oppilaita kannustetaan kysymään apua toisiltaan, auttamaan toisiaan ja jakamaan asiantuntijuuttaan. Yhteistyöstä annetaan hyvää palautetta.

- Tehtävä kannustaa toimimaan niin, että oppilaiden koko kielitaito koetaan tasavertaiseksi ja yhtä arvokkaaksi osaamiseksi kuin opetuskielen taito.

- Eri kieliä käytetään rinnakkain ja limittäin: eri vaiheissa oppimista voi hankkia tietoa, keskustella ja kirjoittaa eri kielillä.

- Tehtävää tehtäessä ja sen lopputuloksessa näkyvät ja kuuluvat oppilaiden osaamat kielet tasavertaisena opetuskielen kanssa. 
- Tehtävä kannustaa oppilaita tutustumaan niihin luokan kieliin, joita he eivät ennestään osaa. Kielellisiin havaintoihin ja oivalluksiin kannustetaan ja niistä annetaan rakentavaa ja arvostavaa palautetta.

Kielitietoisuuden ja limittäiskieleilyn pedagogiikan käytänteiden edut voi tiivistää näin:

- Oppilaat alkavat tunnistaa omat ja toistensa taitoja ja asiantuntijuutta ja arvostaa niitä.

- Luokkahuoneen vuorovaikutuksessa on turvallista ylittää kielten sosiaaliset rajat ja ottaa käyttöön koko kielellinen repertuaari.

- Oppilaat tulevat nähdyksi kokonaisina, mikä tukee monikielisen identiteetin muodostumista.

- Kaikkien kielitietoisuus kasvaa ja asiantuntijuudesta tulee yhteistä ja jaettua.

- Ilmapiiri paranee ja oppilaat auttavat toisiaan aiempaa enemmän.

Hankkeeseen osallistuminen ja kielitietoisen ja limittäiskieleilyn pedagogiikan syvempi ymmärrys ja soveltaminen on muuttanut opettajien työtapoja. Esimerkiksi OPE1:n myöhemmässä työssä kielitietoisuus on yhä näkyvämmässä roolissa: Hän on osallistunut aktiivisesti kielitietoisen opetuksen edelleen kehittämiseen ja täydennyskoulutukseen sekä osallistujana että kouluttajana. Uusien luokkiensa kanssa hän on alusta alkaen soveltanut kielitietoisen ja limittäiskieleilyn pedagogiikan periaatteita ja kehittänyt itse uusia käytänteitä. Toimintatutkimuksen onkin tarkoitus vaikuttaa juuri näin: yksittäiset toimijat levittävät hyviä käytänteitä, ja pienistä puroista kasvaa joki. 


\section{Kirjallisuus}

Aalto, E. \& M. Kauppinen 2011. Tavoitteena monikielisyyttä tukeva äidinkielen ja kirjallisuuden opetus. Teoksessa E. Lehtinen, S. Aaltonen, M. Koskela, E. Nevasaari \& M. Skog-Södersved (toim.) AFinLA-e Soveltavan kielitieteen tutkimuksia 3, 6-21. https://journal.fi/afinla/article/view/4453.

Agha, A. 2007. Language and social relations. Cambridge: Cambridge University Press.

Alisaari, J., L. Heikkola, N. Commins \& E. Acquah 2019. Monolingual ideologies confronting multilingual realities. Finnish teachers' beliefs about linguistic diversity. - Teaching and Teacher Education 80, 48-58. https://doi.org/10.1016/j.tate.2019.01.003.

Blommaert, J. \& A. Backus 2012. Superdiverse repertoires and the individual. - Tilburg Papers in Culture Studies 24. https://www.researchgate.net/publication/292309492_ Repertoires_Revisited_Knowing_Language_in_Superdiversity. 22.10.2020.

Busch, B. 2015. The linguistic repertoire revisited. Applied Linguistics 33 (5), 503-523. https://doi.org/10.1093/applin/ams056.

Creese A. \& A. Blackledge 2015. Translanguaging and identity in educational settings. - Annual Review of Applied Linguistics 35, 20-35. https://doi.org/10.1017/ S0267190514000233.

Commins, N. 2019. Linguistically and culturally responsive pedagogy: Context, orientations and practices. Esitelmä DivEdin, KuKaS:in ja Itä-Helsingin uudet Suomen kielet -hankkeen loppuseminaarissa. 5.11.2019. Helsinki.

Commins, N. \& O. B. Miramontes 2005. Linguistic diversity and teaching. Mahwah: Lawrence Erlbaum.

Coles-Ritchie, M. \& J. Lugo 2008. Implementing a Spanish for heritage speakers course in an English-only state: a collaborative critical teacher action research study. Educational Action Research 18 (2), 197-212. https://doi.org/10.1080/09650791003741061.

Cummins, J. 2000. Language, power, and pedagogy: Bilingual children in the crossfire. Clevedon: Multilingual Matters.

Cummins, J. 2018. Urban Multilingualism and educational achievement: identifying and implementing evidence-based strategies for school improvement. Teoksessa P. Van Avermaet, S. Slembrouck, K. Van Gorp, S. Sierens, K. Maryns, (toim.) The multilingual edge of education. London: Palgrave Macmillan, 67-89.

Dufva, H. 2020. Mitä ihmiset osaavat, kun he osaavat kieltä? Henkilökohtainen repertoaari ja sen multimodaalisuus. Teoksessa S. Grasz, T. Keisanen, F. Oloff, M. Rauniomaa, I. Rautiainen \& M. Siromaa (toim.) Menetelmällisiä käänteitä soveltavassa kielentutkimuksessa - Methodological Turns in Applied Language Studies. AFin-LAn vuosikirja 2020. Suomen soveltavan kielitieteen yhdistyksen julkaisuja 78, 17-32. https://journal.fi/afinlavk/article/view/89461.

French, M. \& J. Armitage 2020. Eroding the monolingual monolith. Australian Journal of Applied Linguistics 3 (1), 91-114. DOI:10.29140/ajal.v3n1.302.

García, O. 2009. Bilingual education in the 21st century: A global perspective. Malden: Blackwell Publishing.

García, O. \& C.E. Sylvan 2011. Pedagogies and practices in multilingual classrooms: singularities in pluralities. The Modern language journal 95 (3), 385-400. DOI:10.1111 /j.1540-4781.2011.01208.

García, O. \& J. A. Kleifgen 2018. Educating emergent bilinguals: policies, programs, and practices for English learners. New York, NY: Teachers College Press.

García O. \& Li Wei 2014. Translanguaging: Language, bilingualism and education. London: Palgrave Macmillan. 
García O., S. I. Johnson \& K. Seltzer 2017. The translanguaging classroom: Leveraging student bilingualism for learning. Philadelphia: Caslon.

Goodwin, C. 1979. The interactive construction of a sentence in natural conversation. Teoksessa P. George (toim.) Everyday language: Studies in ethnomethodology. New York: Irvington publishers, 97-21.

Jørgensen, J. N. 2008. Polylingual languaging around and among children and adolescents. International Journal of Multilingualism 5 (8), 161-176. https://doi. org/10.1080/14790710802387562.

Kalliokoski, J., H. Niemelä \& R. Räty 2020. Kohti monikielistä kouluarkea - miten opetuskieli ja yhteisön muut kielet elävät limittäin? Teoksessa K. Rapatti (toim.) Kaikkien koulu(ksi) - kielitietoisuus koulun kehittämisen kulmakivenä. Äidinkielen opettajain liiton vuosikirja 2020. Helsinki: Äidinkielen opettajain liitto, 207-226.

Lewis, G. B. Jones \& C. Baker 2012. Translanguaging: Origins and development from school to street and beyond. Educational Research and Evaluation 18 (7), 641-654. https://doi.or g/10.1080/13803611.2012.718488.

Li Wei 2018. Translanguaging as a practical theory of language. Applied Linguistics 39 (1), 9-30. https://doi.org/10.1093/applin/amx039.

Lilja, N. \& E. Luukka \& S. Latomaa 2017. Kielitietoisuus eriarvoistumiskehitystä jarruttamassa. Teoksessa S. Latomaa, E. Luukka \& N. Lilja (toim.) Kielitietoisuus eriarvoistuvassa yhteiskunnassa -Language awareness in an increasingly unequal society. AFinLAn vuosikirja 2017. Suomen soveltavan kielitieteen yhdistyksen julkaisuja n:o 75. Jyväskylä, 11-29. https://journal.fi/afinlavk/article/view/66742.

Nugent, K. L. 2020. Exploring the teaching of culture in the foreign language classroom within the context of collaborative professional development: a critical participatory action research study. - Educational Action Research 28 (3), 497-517. https://doi.org/1 0.1080/09650792.2019.1577148.

Lehtonen, H. 2015. Tyylitellen. Nuorten kielelliset resurssit ja kielen sosiaalinen indeksisyys monietnisessä Helsingissä. Helsingin yliopiston suomen kielen, suomalais-ugrilaisten ja pohjoismaisten kielten ja kirjallisuuksien laitos. https://helda.helsinki.fi/ handle/10138/155659.

Lehtonen, H. 2016. Troping on prejudice: Stylised "bad Finnish" performances and reflexivity among adolescents in Eastern Helsinki. - AlLA Review 29 (1), 15-47. https://doi.org/10.1075/aila.29.02leh.

Lehtonen, H. 2019. Monikielisyys koulussa. - Kielikello 4/2019. https://www.kielikello.fi/-/ monikielisyys-koulussa.

Lehtonen, H. \& R. Räty. 2018. Kielitietoisia käytänteitä monikielisessä koulussa: kokemuksia toimintatutkimuksesta. Kieli, koulutus ja yhteiskunta, 9 (3). Saatavilla: https://www. kieliverkosto.fi/fi/journals/kieli-koulutus-ja-yhteiskunta-toukokuu-2018/kielitietoisiakaytanteita-monikielisessa-koulussa-kokemuksia-toimintatutkimuksesta.

Lehtonen, H. \& J. S. Møller (arvioitavana): Moments of interactional upset at school: Linguistic ownership and enregisterment of minority languages in Helsinki and Copenhagen - Special issue Spaces of upset in the Nordic region: Reactions to sociolinguistic change in Denmark, Finland, and Sweden (toim. L. Salö, S. Leppänen, E. Westinen \& D. Karlander). International Journal of the Sociology of Language.

Lehtonen, H. \& S. Pöyhönen 2020. Lingvistinen etnografia toimintayhteisöissä. Teoksessa M. Luodonpää-Manni, M. Hamunen, R. Konstenius, M. Miestamo, U. Nikanne \& K. Sinnemäki (toim.): Kielentutkimuksen menetelmiä I-V. Helsinki: Suomalaisen Kirjallisuuden Seura, 345-374. https://helda.helsinki.fi/handle/10138/323448. 
Lehtonen, H., H. Niemelä, H. Hänninen, A. Siirtola, R. Räty, V. Pelkola, V. Hangaslahti, J. Kalliokoski \& J. Saarikivi. 2020: Monikielisyys näkyväksi, kielitietoutta kaikille! ItäHelsingin uudet Suomen kielet -hankkeen verkkomateriaali. Helsinki: Opetushallitus. https://www.oph.f/fi/monikielisyys-nakyvaksi-kielitietoutta-kaikille.

Madsen, L. M., M.S. Kaerrebaek \& J. S. Møller (toim.) 2015. Everyday languaging: Collaborative research on the language use of children and youth. Trends in Applied Linguistics. Berliini: Mouton de Gruyter.

McNiff, J. 2013. Action Research. Principles and Practice. 3. painos. Lontoo: Routledge.

Møller, J. S. 2019. Recognizing Languages, Practizing Languages. Teoksessa J. Jaspers \& L.M. Madsen 2019 (toim.) Critical perspectives on linguistic fixity and fluidity: Languagised lives. New York: Routledge, 29-52.

Møller, J. S. 2015. The Enregisterment of minority languages in a Danish classroom. Teoksessa Agha, A. \& Frog (toim.) Registers of Communication. Helsinki: Suomalaisen Kirjallisuuden Seura, 107-123.

Rampton, B. 1995. Crossing. Language and ethnicity among adolescents. London: Longman. Rampton, B. 2006. Language in late modernity. Interaction in an urban school. Cambridge: Cambridge University Press.

Rampton, B., J. Maybin J. \& C. Roberts. 2015. Theory and method in linguistic ethnography. Teoksessa J. Snell, S. Shaw \& F. Copland (toim.) Linguistic ethnography. Interdisciplinary explorations. London: Palgrave, 14-50.

Prediger, S. \& L. Wessel 2013. Fostering German-language learners' constructions of meanings for fractions - design and effects of a language- and mathematicsintegrated intervention. Math Ed Res J 25, 435-456. https://doi-org.libproxy.helsinki. fi/10.1007/s13394-013-0079-2.

Svensson, G. \& A-C. Torpsten 2017. Transspråkande för förstärkt flerspråkighet. Teoksessa Å. Wedin (toim.) Språklig mångfald i klassrummet. Stockholm: Lärarförlaget, 37-60.

Tainio, L. (toim.) 2007 Vuorovaikutusta luokkahuoneessa. Näkökulmana keskustelunanalyysi. Helsinki: Gaudeamus.

Tarnanen, M., M. Kauppinen \& A. Ylämäki 2017. Oman äidinkielen tekstitaidot monikielisyyttä rakentamassa - näkökulmia kielille annettuihin merkityksiin ja kielten käyttöön. Teoksessa Latomaa S., E. Luukka \& N. Lilja (toim.) Kielitietoisuus eriarvoistuvassa yhteiskunnassa - Language awareness in an increasingly unequal society. AFinLAn vuosikirja 2017. Suomen soveltavan kielitieteen yhdistyksen julkaisuja n:o 75. Jyväskylä, 278-297.

Tilastokeskus 2021. Väestö. https://www.tilastokeskus.fi/tup/suoluk/suoluk_vaesto.html

Tilastokeskus 2019. Helsingin seudun vieraskielisen väestön ennuste 2018-2035. Helsingin kaupunki. https://www.hel.fi/hel2/tietokeskus/julkaisut/pdf/19_03_14_Tilastoja_3_ Vuori.pdf.

POPS 2014 = Perusopetuksen opetussuunnitelman perusteet. Opetushallitus. https:// www.oph.fi/sites/default/files/documents/perusopetuksen_opetussuunnitelman_ perusteet_2014.pdf.

Winkler, G. 2007. Reflection and theory: conceptualising the gap between teaching experience and teacher expertise. Educational Action Research 9 (3), 437-449. 


\section{Liite: litterointimerkit}

\begin{tabular}{|c|c|}
\hline (puhetta) & epäselvä jakso \\
\hline$(\mathrm{XXXX)}$ & epäselvää puhetta \\
\hline . & laskeva intonaatio \\
\hline , & tasainen tai lievästi laskeva intonaatio \\
\hline / & sävelkulun nousu \\
\hline @puhetta@ & äänenlaadun muutos \\
\hline ((havainto)) & litteroijan kommentteja tai selityksiä \\
\hline (.) & mikrotauko \\
\hline$($ ( ) & mikrotaukoa pidempi mittaamaton tauko \\
\hline$(0.02)$ & tauon pituus \\
\hline $\mathrm{e}<$ & sana tai puheen virta katkeaa kesken \\
\hline
\end{tabular}

Litteraatit noudattavat pääasiassa suomen ortografiaa, poikkeuksena kuitenkin sibilantin merkki š suomalais-ugrilaisen tarkekirjoituksen mukaan sekä vokaalien ł ja u merkintä niin kuin kansainvälisessä foneettisessa kirjoituksessa (IPA, ks. https:// www.internationalphoneticalphabet.org/ipa-sounds/ipa-chart-with-sounds/). 